\title{
The Unexpected and Education: Curriculums for Creativity
}

\author{
Romina Elisondo ${ }^{1}$, Danilo Donolo ${ }^{1}$, María Cristina Rinaudo ${ }^{2}$ \\ ${ }^{1}$ Universidad Nacional de Río Cuarto y Consejo Nacional de Investigaciones \\ Científicas y Técnicas, Río Cuarto, Argentina \\ ${ }^{2}$ Universidad Nacional de Río Cuarto, Río Cuarto, Argentina \\ Email: relisondo@hum.unrc.edu.ar,donolo@hum.unrc.edu.ar, crinaudo@hum.unrc.edu.ar
}

Received October $29^{\text {th }}, 2013$; revised November $28^{\text {th }}, 2013$; accepted December $5^{\text {th }}, 2013$

Copyright (C) 2013 Romina Elisondo et al. This is an open access article distributed under the Creative Commons Attribution License, which permits unrestricted use, distribution, and reproduction in any medium, provided the original work is properly cited. In accordance of the Creative Commons Attribution License all Copyrights (C) 2013 are reserved for SCIRP and the owner of the intellectual property Romina Elisondo et al. All Copyright (C) 2013 are guarded by law and by SCIRP as a guardian.

\begin{abstract}
We propose ourselves to argue about the importance of creating unexpected contexts as a strategy to promote creative processes in education. We have analyzed educational proposals by our team research and specialists' theoretical issues in the field of education and creativity. Our intention is to present theoretical and practical considerations about the role of the unexpected in the promotion of creativity in educational contexts. Learning activities, teachers, contexts, materials and teacher intervention are some of the components of educational contexts that can be designed in an unexpected way to give place to situations for creativity.
\end{abstract}

Keywords: Creativity; Education; Unexpected Activities; Unexpected Teachers; University

\section{Introduction}

Unexpected, Like the papers found in Cortazar's drawer ${ }^{1}$.

For more than a decade, we have focused our attention on creativity in educational contexts (Rinaudo \& Donolo, 1999; Rinaudo \& Donolo, 2000). We have developed general considerations about educational contexts features that offer situations for creativity (Elisondo, Donolo, \& Rinaudo, 2009a). We believe that the construction of creative educational contexts depends on the perceptions and beliefs of the actors with respect to their creativity, expressions and possibilities. We researched on students and teachers' perceptions (Elisondo, Donolo, \& Rinaudo, 2009b, 2011) and analyzed basic beliefs necessary for the construction of educational creative contexts (Elisondo, Rinaudo, \& Donolo, 2011; Elisondo, Donolo, \& Rinaudo, 2012).

It is necessary to think about the relationship between creativity and education beyond the development of a series of pedagogical techniques and creative students' stimulation. We understand that it is relevant to take along a global creative perspective to think about educational transformations towards creativity. We agree with Lin (2011) on the importance of integrating perspectives related to creative teaching, teaching for creativity and creative learning within a general educational framework.

Curricular decisions are based on broad and radical conceptions of creativity (de la Herrán, 2013). In order to generate creative contexts of learning, it is necessary to integrate the proposals that refer to the parts of complex construct: creativity.

${ }^{1}$ Papeles Inesperados (Unexpected Papers), Julio Cortázar's book (2009) edited by Aurora Bernárdez and Carles Álvarez. ALFAGUARA Editorial. Madrid. First pages available in: www.alfaguara.com/uploads/ficheros/libro/ primeras-paginas/200905/primeras-paginas-papeles-inesperados.pdf (30-09-2013).
Generating creative contexts of learning is not to teach divergent thinking techniques or art expression, but to articulate these isolated actions in a general perspective, in an innovative way of understanding education and the role of teachers, students and parents in that new perspective. An integrated and radical perspective involves "releasing a balloon so that it can go up in the air" (de la Herrán, 2013), letting it fly, do, grow, learn and create. New interventions, new thoughts and contexts are created for individuals in creative educational environments.

Socio-cultural perspectives of creativity comprehension and education can help us construct such transformations (Glăveanu, 2013; Craft, 2013). New ways of looking at education, educational proposals as well as teachers and students' actions are essential to promote creative educational contexts. Understanding creative processes as complex and dynamic socio-cultural phenomena is the first basic conception that we must support to transform educational contexts creatively. Creativity and education are socio-cultural processes that are always developed in interaction with others, with different languages and with already built and to-be-built artifacts.

We think that the situations for creativity in educational contexts can be generated inside and outside of the classrooms and institutions. In a previous publication, we have outlined some general characteristics of curricular designs, learning activities, teacher interventions and educational contexts that would give individuals more opportunities for creative processes (Elisondo, Donolo, \& Rinaudo, 2009a).

Extracurricular activities offer different opportunities to develop creative processes (Csikszeenmihalyi, 1996; Davies et al., 2013). In a study carried out at the National University of Rio Cuarto, students state that research extracurricular activities and teacher collaboration offer opportunities for learning and crea- 
tivity that are not always present in classroom contexts. Developing contact with significant people, learning theoretical and practical knowledge, solving complex problems and articulating theory and practice are some of the actions facilitated by participating in extracurricular projects (Elisondo, Donolo, \& Rinaudo, 2009c). The extracurricular activities in a biographical research about Argentinean people well known for their production in different knowledge fields allow learning and interaction with teachers and specialists that positively influence the development of creative processes (Elisondo, 2013).

It is essential to create educational contexts in which creativity is the core of teaching and learning processes, contexts in which diversity, originality and alternatives are possible so that creativity group processes can be promoted and the possibilities of establishing creative bonds, nets and societies can be expanded. It is also of utmost importance to accept integrated, radical and socio-cultural conceptions in the comprehension of creativity in order to create educational contexts. Taking decisions and taking on the risks that these conceptions bring about are also important to transform education creatively.

\section{The Unexpected in Creativity}

Creativity, in its different stages and expressions, is related to the unexpected, surprising and impressive. The creative processes add a series of stages that are developed in a recurrent and complex way (Csikszeenmihalyi, 1996). Preparation (problem delimitation, and the initial search for answers); incubation (unconscious generation of possible solutions to the problem); insight (conscious discovery of the solution to the problem), verification (evaluation of solutions and verification of adaptation) and elaboration (the transformation of ideas into products) are the main elements of the creativity process. At different stages of the process, ideas, images, knowledge, combinations and unexpected products emerge.

Creativity cognitive researchers consider that insight (sudden discovery of the solution to the problem), conceptual expansion (expansion of conceptual frameworks to develop creative ideas), recently activated knowledge (activated knowledge due to the individual's new experiences), conceptual combination (synthesis of concepts previously divided) and mental images (valid meaning patterns) are the main cognitive components of creative thinking (Ward, Smith, \& Finke, 1999). Such cognitive processes are combined in a complex way and, sometimes, unexpectedly during the development of creativity (Smith, 2011). It is almost impossible to anticipate the forms and peculiarities of cognitive processes during creative production and thinking, it is not easy to predict the unexpected multiple connections that take place during creativity.

Resent research analyze the effect of unusual and unexpected situations in creative processes from different perspectives. The multicultural experiences and the exchange in unexpected contexts seem to be closely related to creative possibilities (Leung y Chiu, 2008, 2010; Leung, Maddux, Galinsky, \& Chiu, 2008; Maddux \& Galinsky, 2009; Maddux, Adam, \& Galinsky, 2010). Ritter, Rodica, Damian, Simonton, van Baaren, Strick, Derks \& Dijksterhuis (2012) conclude that unexpected situations, created experimentally through virtual simulations, generate flexible cognitive processes and are related to creativity. In short, some research on natural and artificial contexts shows that creativity is related to the unusual and unexpected events and experiences.
The unexpected is also related to an important concept in order to understand the initial stages of creative processes: mini creativity. Mini-c is creativity that is inherent in all learning process and is defined as new and personal interpretations based on individuals' actions, experiences and events (Beghetto y Kaufman, 2007; Kaufman y Beghetto, 2009; Kaufman, Beghetto, \& Baer e Ivcevic, 2010). It is about new insight for individuals, which generally takes place suddenly and unexpectedly. Individuals experience mini-creativities permanently during the learning process. Assessment of mini creativity is always subjective; insights are creative, original and new for each individual when generated.

Craft's studies on thinking possibilities also provide arguments about the infinite and unexpected of thoughts and creativity (Craft, 2013). What if? is the question used in classes and experimental situations to favor the emergence of unexpected ideas, thoughts and expressions. Beghetto (2007, 2013a, 2013b) also considers that the unexpected is the way to promote creativity in classes. The researcher assigns an outstanding value to the unexpected questions and ideas that emerge during the exchange between the teachers and students in classes. The unexpected questions generate interesting micro moments in classes to promote creativity, micro moments that must be recognized and used by teachers.

Improvisation, which always adds unexpected elements, is an important creative source (Lemons, 2005; Sawyer, 2004, 2006). Improvisation assumes unexpected actions and creates new actions, meanings and experiences. Close relations can be seen between the unexpected, improvisation and creative processes. The curricular decisions oriented to creativity must be taken with some disciplined improvisation (Sawyer, 2004, 2011; Beghetto \& Kaufman, 2011), that is, allowing for some planning for spontaneity, freedom and the unexpected.

The emergence of ideas and mental images, their combination and amplification of knowledge diagrams are produced suddenly, unexpectedly and surprisingly. This seems to be the main characteristic of creative processes. At the same time, these processes allow to create new problems and products that are also unexpected and essential. All the creative process, from the ideas emergence up to their transformation in products, seems to take place unexpectedly and uncertainly even for the own individual. Creative ideas and products are also unexpected for others, for members of specialized areas and for society in general. This is why they initially cause rejection uncertainty and incomprehension in general.

Creativity development processes are full of unexpected components and situations. Notwithstanding, this does not mean that the ideas and creative products emerge easily and by chance. On the contrary, the unfolding of creative processes implies effort, dedication and perseverance. The unexpected components of creativity emerge thanks to the effort dedication and perseverance of people and groups. The unexpected ideas and products only emerge when theoretical and practical knowledge on the fields is available and when people and groups are devoted and think constantly about certain topics and problems.

Creative processes have a lot of unexpected, uncertain and unpredictable situations that give place to uncertainty, motivation, surprise and the desire to walk unexplored short cuts and pathways. The curricular decisions acquire innovative characteristics when the unexpected allows for new relations between creativity and education. The proposals presented below are 
planning items for the unexpected; we do not wait for the unexpected as Beghetto (2013a), but we take curricular decisions and provoke unexpected situations deliberately. The unexpected is not only welcome (Rusell \& Wyse, 2013), it is intentionally built and proposed in educational contexts. Productions, redefinitions and transformations of proposals are also unexpected, following our argument logic. Curricular planning of unexpected activities, exchanges, materials and spaces enables multiple paths to walk in search of thoughts, expressions and creative productions.

\section{Unexpected Proposals at the University}

Adding unexpected elements to educational contexts gives place to situations for creativity, that is, opportunities that can be available for students and teachers to develop creative processes. Even though it is not possible to teach individuals to be creative directly, it is feasible to create situations so that creativity can take place in educational contexts. We are interested in sharing our initial unexpected proposals with students from National University from Rio Cuarto. We have briefly described activities that aim at creating significant experiences and educational environments that promote creativity. The proposals presented are innovations within specific frameworks and private classes, maybe the integration of such activities in more integrated planning contribute significantly in the construction of wide creative contexts in higher education.

The Suitcase of Grandmother Cristina is an unexpected activity that we developed with graduate and postgraduate students (Elisondo, Rinaudo, \& Donolo, 2011). The activity design was supported by theoretical considerations that hold the integration of activities with strange, abnormal and out of context objects, as teacher intervention to promote creativity. In unexpected activities, the tasks, objects, students' demands and emerging results or products are unforeseeable. In The Suitcase of Grandmother Cristina, students in groups were asked to write a meaningful text and then interrelate at least three unexpected objects taken from the suitcase. In The Suitcase of Grandmother Cristina, students could find the following elements: a toy shoe, an old metronome, a modern metronome, a silicone mate and an object that creates holograms. The groups created unexpected rich and diverse productions; participants' fantasies, games, experiences and emotions were integrated in the texts. Most groups commented on childhood experiences related to games and imagination.

The Suitcase of Grandmother Cristina was an unexpected activity for the contexts in which it was developed; university classrooms that allowed individuals to recover childhood emotional and playful experiences; create original productions and relate the proposal to learning expected contexts (Elisondo \& Rinaudo y Donolo, 2011).

Unexpected teachers, who did not belong to our department, were invited to the classes with university students of Counseling, Special Education and Initial education. From our point of view and accepting a socio-cultural perspective of comprehension of creative processes, we understand that unexpected teachers can make important contributions to students' learning process and creativity promotion. Unexpected teachers allowed students to establish contact with other people, know different points of view and unexpected knowledge according to the educational programs established (Elisondo, Donolo, \& Rinaudo, 2012).
We also offer students unexpected links so that they can surf countless places on the web and find knowledge and unlimited ideas; and can walk unexplored paths (Elisondo, Donolo, \& Rinaudo, 2013a). The links proposed show advances, developments and scientific and technological enigmas in different knowledge fields. The inclusion of unexpected links in the course syllabus, activities and evaluations is supported by considerations related to knowledge fluency and dynamism and the need to build strategies and procedures related to information literacy. The provisional, dynamic and complex nature of knowledge that is produced and communicate second by second question us to create educational proposals in which students recognize at least the importance and need to know how to search, select, understand and produce information in different formats and contexts. The links also open unexpected and endless paths to navigate while each link can take to a thousand new pages which in turn provide with unlimited learning possibilities. Regarding the course syllabus, the links move away from what has been established in the programs and allow building unexpected, original and new relations between prescribed knowledge and knowledge that flows. Links give power, while knowing is a valuable weapon to take decisions in everyday life, social networks, academic education and future career.

Our proposals include visits to unexpected places such as virtual libraries (Elisondo, Donolo, \& Rinaudo, 2013b). Maybe, it would seem that libraries cannot be considered unexpected places in higher education, however, and according to students' comments, not only traditional but also virtual libraries are not places of frequent visit during higher education. Going to the library is an unexpected invitation for many students that we have interacted. In both virtual and traditional libraries, students encounter interesting treasures, unexplored paths, knowledge, original ideas, alternative perspectives and things to read, do and question. The planned visits to unexpected places where to do unexpected actions is for us a curricular decision oriented to creativity promotion in higher education. The unexpected links and the visits to virtual libraries are activities that allow to articulate initial proposals of information literacy, science communication and creativity at the university.

When we were unexpectedly proposed to teach Creativity, subject of the first year of Initial Education at the National University of Rio Cuarto, we considered that we should provide educational contexts where learning unexpected experiences could be built (Elisondo \& Donolo y Rinaudo, 2013c). Some curricular decisions were taken, the activities, contents, teachers and evaluations acquired some unexpected characteristics. We designed many opportunities to do, that is to say, different learning activities that allowed building knowledge, integrating ideas and curricular contents among students. Our syllabus was made with expected and unexpected contents that included different perspectives in the research field of creativity and multiple possibilities for teaching practices. Results were also unexpected; students built educational resources, didactic units, objects, ties and emotions that surprised us. Students' productions stood out because of their originality and theoretical soundness regarding argument. In evaluations, teachers and students recovered the value of significant experiences in building creative contexts of teaching and learning processes.

The unexpected creates an innovative, different and dynamic context in which it is possible to develop ideas, create products and interact with others in different ways. The unexpected opens possibilities also unexpected to learn in a different way in 
higher education contexts.

The proposals described are backed up by supported theoretical curricular decisions; we do not do what first comes to our mind to create the unexpected but we plan in detail and based on theoretical considerations about education and creativity. The results observed in students' productions and interpretations are favorable and encouraging. Students say they find opportunities in the unexpected proposals to think, feel, develop ideas, create products and continue learning. It probably seems a contradiction to talk about an unexpected curriculum, since the curricular notion refers necessarily to the planning of expected events.

However, we believe that taking curricular decisions to plan the unexpected is an interesting way to create innovative contexts in the teaching and learning processes.

\section{Final Considerations}

The unexpected includes new ways of thinking educational contexts. It goes against monotonous activities, doing the same thing and always obtaining the same results. The unexpected characterizes the creative processes, redefines, transforms and makes them singular and complex. Proposing educational contexts using unexpected components may be a new way to break established practice and allow space for, improvisation and creativity. The unexpected creates opportunities not only for students but also for teachers. Building new ways of teaching that move beyond predictable and expected tasks may enrich teaching practice and professional development

Curricular decisions that include unexpected components may allow teaching and learning contexts in which knowledge, emotions and significance tie with others and with cultural artifacts. Technology information and communication, for example, offer numerous unexpected opportunities to learn and create. Knowledge that is built can be unexpected and, in many cases, undisciplined.

Besides introducing some particular proposals, our intention is to think the unexpected in a general way as a strategy to create new learning contexts focused on creativity. Each teacher interacting with students will build particular proposals and experiences as unexpected components. We consider that the unexpected provides interesting aspects to think about wide educational proposals that go beyond the regular tasks and planning of some teachers. Broadly speaking, the unexpected offers elements to think about innovative educational contexts, in which the didactic triangle can be seen from a different perspective that can recognize teachers and students' potential and at the same time, recognize the dynamic and complex nature of curricular contents. It is essential to foster thinking and learning possibilities from the construction of significant interactions with others and cultural tool, socio-cultural diagrams on education and creativity provide interesting analytical frameworks in this sense.

Considering education from another perspective also implies unexpected and unpredictable risks that not all teachers are willing to run. After all, creativity, as Sternberg (2006) says, is a decision. Generating creative educational contexts also involves decisions and risks.

\section{REFERENCES}

Beghetto, R. (2007). Does creativity have a place in classroom dis- cussions? Prospective teachers' response preferences. Thinking Skills and Creativity, 2, 1-9.

http://dx.doi.org/10.1016/j.tsc.2006.09.002

Beghetto, R. (2013a). Expect the unexpected: Teaching for creativity in the micromoments. In M. Gregerson, H. Snyder, \& J. Kaufman (Eds.), Teaching creatively and teaching creativity (pp. 133-148). London: Springer.

http://pages.uoregon.edu/beghetto/ExpectedUnexpected(Beghetto,inp ress).pdf

Beghetto, R. (2013b). Nurturing creativity in the micro-moments of the classroom. In K. Kim, J. Kaufman, J. Baer, \& B. Sriraman (Eds.), Creatively gifted students are not like other gifted students: Research, theory, and practice (pp. 3-16).

http://pages.uoregon.edu/beghetto/CreativityinMicromoments\%20(B eghetto, \%202013).pdf

Beghetto, R., \& Kaufman, J. (2011). Teaching for creativity with disciplined improvisation. In R. Sawyer (Ed.), Structure and improvisation in creative teaching (pp. 94-109). Cambridge: Cambridge University Press. http://dx.doi.org/10.1017/CBO9780511997105.006

Beghetto, R., \& Kaufman, J. (2007). Toward a broader conception of creativity: A case for mini-c creativity. Psychology of Aesthetics, Creativity, and the Arts, 1, 73-79. http://dx.doi.org/10.1037/1931-3896.1.2.73

Craft, A. (2013). Childhood, possibility thinking and education futures. International Journal of Educational Research, 61, 126-134. http://dx.doi.org/10.1016/j.ijer.2013.02.005

Csikszeenmihalyi, M. (1996). Creatividad. El fluir y la psicología del descubrimiento y la invención. Paidós: Barcelona.

Davies, D., Jindal-Snape, D., Collier, C., Digby, R., Hay, P., \& Howe, A. (2013). Creative learning environments in education: A systematic literature review. Thinking Skills and Creativity, 8, 80-91. http://dx.doi.org/10.1016/j.tsc.2012.07.004

De la herran, A. (2013) Creatividad y formación radical: Cuando la creatividad no sirve para nada. Conferece in I Congreso Internacional de Investigación y Docencia en la Creación Artística se celebrará en el Centro de Magisterio La Inmaculada, adscrito a la Universidad de Granada, el 05 y 06 september 2013.

$\mathrm{http}: / / \mathrm{www}$.youtube.com/watch? $\mathrm{v}=$ Vool2W5hDRo

Elisondo, R. (2013). La creatividad en personas comunes. Potencialidades en Contextos cotidianos. En Donolo y Elisondo (Coordinadores) Estudio de Creatividad. Las travesías de Alfonsina, de Astor, de Julios y de Marías. Colección Cuadernos de Bellas Artes. No10. Tenerife: Sociedad Latina de Comunicación Social. http://issuu.com/revistalatinadecomunicacion/docs/10cbadonolo

Elisondo, R., Donolo, D., \& Rinaudo, M. (2013a). Un poco de ciencia para estudiantes universitarios. Links inesperados en la formación académica. III Congreso Internacional de Comunicación Pública de la Ciencia, Universidad Nacional de Rosario, 12-14 de septiembre de 2013.

Elisondo, R., Donolo, D., \& Rinaudo, M. (2013b). No sabemos ni cómo, ni dónde buscar. Alfabetizaciones, tecnologías y ciencias. III Congreso Internacional de Comunicación Pública de la Ciencia, Universidad Nacional de Rosario, 12-14 de Septiembre de 2013.

Elisondo, R., Donolo, D., \& Rinaudo, M. (2013c). Experiencias inesperadas de creatividad en la asignatura Creatividad. I Congreso Internacional de Investigación y Docencia en la Creación Artística se celebrará en el Centro de Magisterio La Inmaculada, adscrito a la Universidad de Granada, 5-6 de Septiembre de 2013.

Elisondo, R., Donolo, D., \& Rinaudo, M. (2012). Docentes inesperados y creatividad. Revista Electrónica de Investigación Docencia y Creatividad, 1, 103-114.

https://docs.google.com/file/d/0B5Sju9aeFZ8AN29qNVhlOFlscFU/e dit?pli=1

Elisondo, R., Rinaudo, M., \& Donolo, D. (2011). Actividades inesperadas como oportunidades para la creatividad. Contextos creativos en la Educación Superior Argentina. Revista Innovación Educativa (México), 11, 147-156.

http://www.autoriawcm.ipn.mx/wps/wcm/connect/78451b004b1d042 db565fd7b759ccbee $/ 57$ Actividades inesperadas.pdf?MOD=AJPER ES\&ContentCache $=$ NONE\&CACHEID $=78451 \mathrm{~b} 004 \mathrm{~b} 1 \mathrm{~d} 042 \mathrm{db} 565 \mathrm{fd}$ $7 \mathrm{~b} 759$ ccbee 
Elisondo, R., Donolo, D., \& Rinaudo, M. (2011). Contextos educativos creativos: Perspectivas de los profesores. En innovación educativa en la enseñanza formal. Murcia: Ediciones de la Universidad de Murcia. http://edit.um.es/library/docs/books/9788469428429.pdf

Elisondo, R., Donolo, D., \& Rinaudo, M. (2009a). Ocasiones para la creatividad en contextos de educación superior. Revista de Docencia Universitaria, 4. http://revistas.um.es/redu/article/view/92571/89061

Elisondo, R., Donolo, D., \& Rinaudo, M. (2009b). Contextos de educación en la universidad. Perspectivas de los alumnos potencialmente más creativos. Revista Iberoamericana de Educación, 49, 1-18. http://www.rieoei.org/2725.htm

Elisondo, R., Donolo, D., \& Rinaudo, M. (2009c). Oportunidades para la creatividad en la Universidad: las actividades extra-curriculares. III Congreso Internacional de Educación, Universidad del Litoral. 5-7 de Agosto de 2009.

Glăveanu, V. (2013). Rewriting the language of creativity: The five A's framework. Review of General Psychology, 17, 69-81. http://dx.doi.org/10.1037/a0029528

Kaufman, J., \& Beghetto, R. (2009). Beyond big and little: The four C model of creativity. Review of General Psychology, 13, 1-12. http://dx.doi.org/10.1037/a0013688

Kaufman, J., Beghetto, R., Baer, J., \& Ivcevic, Z. (2010) Creativity polymathy: What Benjamin Franklin can teach your kindergartener. Learning and Individual Differences, 20, 380-387. http://dx.doi.org/10.1016/i.lindif.2009.10.001

Lemons, G. (2005). When the horse drinks: Enhancing everyday creativity using elements of improvisation. Creativity Research Journal, 17, 25-36. http://dx.doi.org/10.1207/s15326934crj1701 3

Leung, A. K., \& Chiu, C. (2008). Interactive effects of multicultural experiences and openness to experience on creative potential. Creativity Research Journal, 20, 376-382. http://dx.doi.org/10.1080/10400410802391371

Leung, A. K., \& Chiu, C. (2010). Multicultural experiences, idea recaptiveness, and creativity. Journal of Cross-Cultural Psychology, 41, 723-741. http://dx.doi.org/10.1177/0022022110361707

Leung, A. K., Maddux, W. W., Galinsky, A. D., \& Chiu, C. (2008). Multicultural experience enhances creativity: The when and how. American Psychologist, 63, 169-181.

http://dx.doi.org/10.1037/0003-066X.63.3.169

Lin, Y. (2011). Fostering creativity through education-A conceptual framework of creative pedagogy. Creative Education, 2, 149-155. http://dx.doi.org/10.4236/ce.2011.23021

Maddux, W. W., Adam, H., \& Galinsky, A. D. (2010). When in Rome...learn why the Romans do what they do: How multicultural learning experiences enhance creativity. Personality and Social Psychology Bulletin, 36, 731-741 http://dx.doi.org/10.1177/0146167210367786

Maddux, W. W., \& Galinsky, A. D. (2009). Cultural borders and mental barriers: The relationship between living abroad and creativity. Journal of Personality and Social Psychology, 96, 1047-1061. http://dx.doi.org/10.1037/a0014861

Rinaudo, M., \& Donolo, D. (1999). Creatividad en educación? Retos actuales de la enseñanza universitaria. Contextos de Educación, 1, 202-219. http://www.unrc.edu.ar/publicar/cde/contexto.htm

Rinaudo, M., \& Donolo, D. (2000). Casandra y la educación. En GUERCI de SIUFI, B. Pensando la Universidad. Jujuy: Editorial UNJU y Red de Editoriales de Universidades Nacionales.

Ritter, S., Damian, R., Simonton, D., van Baaren, R., Strick, M., Derks, J., \& Dijksterhuis, A. (2012). Diversifying experiences enhance cognitive flexibility. Journal of Experimental Social Psychology, 48, 961-964. http://dx.doi.org/10.1016/j.jesp.2012.02.009

Russell, J.. \&. Wyse, D. (2013). Creativity across the curriculum. In J. Russell, \& D. Wyse (Eds.), Creativity in the primary curriculum. Oxon: Routledge.

Sawey, K. (2004). Creative teaching: Collaborative discussion as disciplined improvisation. Educational Researcher, 33, 12-20. http://dx.doi.org/10.3102/0013189X033002012

Sawyer, R. (2011). Structure and improvisation in creative teaching. Cambridge: Cambridge University Press. http://dx.doi.org/10.1017/CBO9780511997105

Sawyer, K. (2006). Explaining creativity: The science of human innovation. New York: Oxford University Press.

Smith, S. (2011) Incubation. In M. Runco, \& S. Pritzker (Eds.), Encyclopedia of creativity (pp. 653-657). New York: Elsevier. http://dx.doi.org/10.1016/B978-0-12-375038-9.00121-7

Sternberg, R. (2006). The nature of creativity. Creativity Research Journal, 18, 87-98.

http://dx.doi.org/10.1207/s15326934crj1801_10

Ward, T., Smith, S.. \& Finke, R. (1999). Creative cognition. In R. Sternberg (Ed.), Handbook of creativity. New York: Cambridge University Press. 